\title{
BOARD DIVERSITY, UKURAN PERUSAHAAN DAN INTELLECTUAL CAPITAL DISCLOSURE BANK UMUM SYARIAH
}

\author{
Ilhamdi dan Neng Evi Silvia Arianti \\ Sekolah Tinggi Ekonomi Islam SEBI \\ Email:Ilham_hamdi03@yahoo.com; nengevisilviaarianti@gmail.com
}

\begin{abstract}
This study aims to analyze the factors that affect the disclosure of intellectual capital, namely board diversity and firm size. The samples used were secondary data from Annual Report of Islamic Banks that registered in the BI during the observation period 2011-2015. Sampels were taken with a purposive sampling method, and who meet the criteria for sample selection. Content analysis was employed in this study to determine the Intelectual Capital Disclosure (ICD). The study used panel data analysis to investigate the influence of board diversity and firm size on ICD. Content analysis show that the ICD indeks of Islamic banks has increased over period of study. Panel data analysis indicate that board diversity and firm size simultaneously affect the ICD indeks. Partially, firm size has positive significant effect to ICD. Board diversity namely women directors show negative significant effect to ICD. However, board diversity namely independent directors is not influence to ICD.
\end{abstract}

Keywords: Intellectual Capital Disclosure (ICD), Women Directors, Independent Directors, Firm Size, Content Analysis, Panel Data Analysis

\section{PENDAHULUAN}

Perkembangan perbankan syariah saat ini dari sisi aset maupun pangsa pasar membukukan pertumbuhan yang signifikan. Menurut data Statistik Perbankan Syariah yang dikeluarkan Otoritas Jasa Keuangan (OJK), sampai dengan Desember 2015 aset perbankan syariah mencapai Rp 296.262 triliun. Dimana pada tahun 2008 asetnya hanya sebesar $0,11 \%$ dari total aset perbankan nasional, sedangkan sekarang telah mencapai $4,8 \%$ yang berarti telah terjadi peningkatan yang signifikan. Per Desember 2015, perbankan syariah berjumlah 12 Bank Umum Syariah (BUS) dan 22 Unit Usaha Syariah (UUS) dimana pada awal tahun 2005 hanya ada 3 BUS yaitu Bank Muamalat Indonesia, Bank Syariah Mandiri, dan Bank Mega Syariah. Pada tahun ini, terhitung sejak September 2016, terdapat 13 BUS, 21 UUS, dan 165 BPRS. Jaringannya pun telah mencapai 2.301 kantor yang terdiri dari 588 kantor cabang (KC)/kantor pusat operasional (KPO), 1.469 kantor cabang pembantu (KCP)/unit pelayanan syariah (UPS), dan 244 kantor kas (KK).

Selain itu perkembangan perbankan syariah dapat dilihat juga dari jumlah tenaga kerja yang merupakan modal utama dari industri sektor jasa. Statistik Desember 2015 mencatat sebanyak 55.816 orang tenaga kerja perbankan syariah di Indonesia. Dengan angka tenaga kerja yang besar ini, 
perbankan syariah dapat tumbuh menjadi semakin besar, karena salah satu kekuatan nyata dan penting dimana ia memberikan pelayanan terbaik, mengembangkan produk-produk menjadi lebih inovatif, dan membawa perusahaan mencapai targetnya merupakan usaha dari para tenaga kerja yang perlu dihargai sebagai modal yang potensial.

Perbankan syariah pada era globalisasi saat ini dituntut untuk dapat bersaing dengan industri perbankan lainnya. Hal ini tersebut mendorong perbankan syariah untuk melakukan efisiensi dalam kegiatan bisnisnya. Salah satunya adalah dengan melakukan perubahan cara kerja berdasarkan tenaga kerja (labor-based business) menjadi berdasarkan pengetahuan (knowledgebased business).

Ketika basis perusahaan berubah menjadi knowledge-based business, maka otomatis sistem manajemen perusahaan pun akan berubah berdasarkan pengetahuan. Dalam sistem manajemen pengetahuan, modal konvensional atau modal yang berwujud seperti sumber daya alam, sumber daya keuangan, dan aktiva fisik lainnya menjadi kurang penting dibanding dengan modal yang berbasis pada pengetahuan dan teknologi karena penghargaan pasar terhadap nilai perusahaan lebih dilihat dari modal-modal yang tidak berwujud (Sawarjuwono \& Kadir, 2003).

Sebagai sebuah konsep, modal-modal non fisik atau yang tidak berwujud merujuk kepada Intellectual Capital (Rupidara, 2008). Sebagai asset strategis perusahaah, Intellectual Capital menjadi salah satu instrumen untuk menentukan nilai perusahaan (Ulum, 2008). Selain itu, Intellectual Capital juga dapat meningkatkan keuntungan perusahaan yang labanya dipengaruhi oleh inovasi dan knowledge-intensive services (Suhardjanto \& Wardhani, 2007). Dengan meningkatnya intellectual capital, pada dasarnya akan membantu perusahaan menjadi lebih efisien, efektif, dan produktif (Muslih \& Artinah, 2011) yang pada akhirnya akan memajukan organisasi dan masyarakat (Rupidara, 2008).

Pengungkapan Intellectual Capital dianggap penting dalam menemukan hidden value perusahaan. Hidden value perusahaan akan terlihat ketika adanya perbedaan (gap) antara nilai pasar (market value) perusahaan dengan nilai aset (asset value) perusahaan yang tercatat dalam laporan keuangan. Dan beberapa peneliti telah menemukan adanya gap yang besar antara nilai pasar dengan nilai buku yang diungkapkan karena perusahaan telah gagal melaporkan hidden value dalam laporan tahunannya (Mouritsen, Thorbjørnsen, Bukh, \& Johansen, 2004). Contohnya perusahaan-perusahaan di atas hanya memiliki net assets yang kurang dari 50\% market value. Itu berarti kemampuan perusahaan dalam meningkatkan company's value bukan dalam tangible asset, melainkan dalam intangible intellectual asset (Edvinsson \& Sullivan, 1996). Harrison dan Sr (2000) juga menyebutkan bahwa intangible assets merupakan penentu utama dalam profit perusahaan. Faktanya, elemen-elemen intellectual capital merupakan kekuatan nyata perusahaan dalam memproduksi, mengembangkan, dan membawa perusahaan ke arah masa depan gemilang (Sawarjuwono \& Kadir, 2003). 
Perhatian terhadap praktik pengelolaan intangible assets telah meningkat tajam sejak tahun 1990-an (Harrison \& Sr, 2000). Salah satu pendekatan yang digunakan dalam penilaian dan pengukuran intangible assest tersebut adalah intellectual capital yang telah menjadi fokus perhatian dalam berbagai bidang, baik manajemen, teknologi informasi, sosiologi, maupun akuntansi (Ulum, Ghozali, \& Chariri, 2008). Semakin bernilainya intellectual capital sebagai aset perusahaan telah memberikan tantangan tersendiri bagi para akuntan untuk mengidentifikasi, mengukur, dan mengungkapkannya ke dalam laporan keuangan perusahaan (Stephani \& Yuyetta, 2011).

Manfaat dari pengungkapan intellectual capital adalah dapat meningkatkan relevansi laporan keuangan, meningkatkan kepercayaan dan loyalitas karyawan serta stakeholder lainnya, juga perusahaan dapat memberi bukti tentang nilai sesungguhnya perusahaan dan kemampuan penciptaan kekayaan perusahaan (Brüggen, Vergauwen, \& Dao, 2009). Chen \& Li (2005) juga mengungkapkan bahwa perusahaan yang memiliki nilai intellectual capital yang lebih tinggi akan lebih bernilai bagi investor dibandingkan perusahaan yang memiliki intellectual capital yang lebih rendah. Apalagi untuk industri yang bergerak pada sektor jasa, basis kerjanya lebih kepada pelayanan pelanggan (customer service) yang mengandalkan kualitas human capital, maka pengungkapan intellectual capital akan sangat mempengaruhi nilai perusahaan jasa tersebut karena elemen intellectual capital terdiri dari human capital, structural capital, dan customer capital.

Hasil penelitian Oktavianti \& Wahidahwati (2014) menunjukkan bahwa pengungkapan intellectual capital perusahaan manufaktur yang terdaftar di Bursa Efek Indonesia (BEI) masih tergolong rendah dengan ratarata sebesar $28,1 \%$. Begitu pula pengungkapan intellectual capital seluruh perusahaan di Indonesia yang terdaftar di BEI hanya sekitar 43,15\% (Astuti \& Wirama, 2016). Lain halnya penelitian yang dilakukan oleh Ulum (2011) dengan objek perusahaan telekomunikasi di Indonesia menyatakan bahwa pengungkapan intellectual capital sudah relatif tinggi. Pengungkapan intellectual capital ini akan mempengaruhi kinerja perusahaan dalam lingkungan yang kompetitif (Ulum, 2008).

Hubungan kinerja perusahaan dan praktik tata kelola perusahaan menjadi masalah yang amat menarik bagi penelitian akademik maupun masyarakat umum untuk beberapa dekade ini (Swartz, 2006). Salah satu elemen penting dari tata kelola perusahaan adalah komposisi/struktur dewan direksi (Board Diversity). Dewan direksi dianggap sebagai alat yang penting dalam membuat, mengembangkan dan mengelola intellectual capital melalui penataan dan pembentukan strategi dan kebijakkan yang relevan (Al-Musalli \& Ismail, 2012). Komposisi dewan direksi yang beragam akan meningkatkan efektivitas dan kemandirian dewan, meningkatkan pengambilan keputusan dewan, meningkatkan kinerja sosial (Hanefah, 2016) dan apabila dewan direksi mengerjakan tugasnya secara efektif, nilai perusahaan akan cenderung meningkat maka kekayaan pemegang saham pun akan meningkat pula (Swartz, 2006). 
Selain itu, faktor yang tak kalah penting dalam pengungkapan intellectual capital adalah ukuran (size) perusahaan. Karena perusahaan besar didukung dengan sumber daya yang memadai akan mengungkapkan lebih banyak informasi dimana pengungkapan yang lebih luas akan memberi gambaran perusahaan kepada pengguna informasi (Astuti \& Wirama, 2016). Pengaruh signifikan ukuran perusahaan terhadap intellectual capital ditunjukkan dalam penelitian Astuti \& Wirama (2016), Suhardjanto \& Wardhani (2007), Stephani \& Yuyetta (2011). Namun dalam penelitian Sudarmadji \& Sularto (2007) terungkap bahwa ukuran perusahaan dinyatakan tidak berpengaruh terhadap pengungkapan intellectual capital. Sehingga diperlukan juga pengujian ulang terhadap variabel ini.

\section{METODE PENELITIAN}

Studi ini menggunakan dua jenis penelitian yaitu penelitian kualitatif dengan menggunakan pendekatan analisis dokumen (content analysis). Content analysis dilakukan dengan mengumpulkan data dan informasi melalui pengujian arsip dan dokumen (Umar, 2000). Hal tersebut dilakukan untuk mengetahui seberapa besar tingkat pengungkapan dari indeks ICD.

Sementara penelitian kuantitatif dilakukan dengan menggunakan regresi data panel. Hal tersebut digunakan untuk menganalisis suatu hubungan pengaruh dimana variabel-variabelnya sudah ditentukan dengan jelas. Metode ini lebih spesifik, sistematis, terencana, dan terstruktur dari awal hingga kesimpulan karena data yang digunakan lebih menekankan pada penggunaan angka-angka. Data dalam penelitian ini diantaranya intellectual capital index sebagai proksi intellectual capital disclosure (ICD), rasio keterwakilan perempuan sebagai proksi jenis kelamin, rasio direksi independen sebagai proksi direksi independen, rasio direksi asing sebagai proksi kebangsaan, dan log natural total aset sebagai proksi size perusahaan.

\subsection{VARIABEL DEPENDEN}

Variabel dependen yang digunakan dalam penelitian ini adalah intellectual Capital Disclosure (ICD). ICD pada penelitian ini akan diproksikan dengan menggunakan Intellectual Capital Disclosure Index berdasarkan 36 item yang digunakan (Ulum, 2015) dimana merupakan hasil modifikasi (M) skema Guthri et.al (1999) dengan menambahkan beberapa item yang diatur dalam Keputusan Ketua Bapepam dan LK Nomor: Kep-431/BL/2012 tentang Penyampaian Laporan Tahunan Emiten atau Perusahaan Publik. Item-item ICD yang digunakan dalam penelitian ini dapat dilihat pada Tabel 1.

Tabel 1. Item-Item Indeks Pengungkapan Intellectual Capital (36 Item)

\begin{tabular}{lll}
\hline Kategori & \multicolumn{2}{l}{ Item Pengungkapan } \\
\hline Human Capital & 1. & Jumlah karyawan (M) \\
& 2. & Level pendidikan \\
& 3. & Kualifikasi karyawan \\
& 4. & Pengetahuan karyawan \\
\hline
\end{tabular}




\begin{tabular}{|c|c|c|}
\hline & $\begin{array}{l}5 . \\
6 . \\
7 . \\
8 .\end{array}$ & $\begin{array}{l}\text { Kompetensi karyawan } \\
\text { Pendidikan dan pelatihan }(\mathrm{M}) \\
\text { Jenis pelatihan terkait }(\mathrm{M}) \\
\text { Turn over karyawan }(\mathrm{M})\end{array}$ \\
\hline Structural Capital & $\begin{array}{l}9 . \\
10 . \\
11 . \\
12 . \\
13 . \\
14 . \\
15 . \\
16 . \\
17 . \\
18 . \\
19 . \\
20 . \\
21 . \\
22 . \\
23 .\end{array}$ & $\begin{array}{l}\text { Visi misi (M) } \\
\text { Kode etik (M) } \\
\text { Hak paten } \\
\text { Hak cipta } \\
\text { Trademarks } \\
\text { Filosofi managemen } \\
\text { Budaya organisasi } \\
\text { Proses manajemen } \\
\text { Sistem informasi } \\
\text { Sistem jaringan } \\
\text { Corporate governance (M) } \\
\text { Sistem pelaporan pelanggaran } \\
\text { (M) keuangan } \\
\text { Analisis kinerja } \\
\text { komprehensif } \\
\text { Kemampuan membayar hutang } \\
\text { (M) } \\
\text { Struktur permodalan (M) }\end{array}$ \\
\hline Relational Capital & $\begin{array}{l}24 . \\
25 . \\
26 . \\
27 . \\
28 . \\
29 . \\
30 . \\
31 . \\
32 . \\
33 . \\
34 . \\
35 . \\
36 .\end{array}$ & $\begin{array}{l}\text { Brand } \\
\text { Pelanggan } \\
\text { Loyalitas pelanggan } \\
\text { Nama perusahaan } \\
\text { Jaringan distribusi } \\
\text { Kolaborasi bisnis } \\
\text { Perjanjian lisensi } \\
\text { Kontrak-kontrak } \\
\text { menguntungkan } \\
\text { Perjanjian franchise } \\
\text { Penghargaan }(\mathrm{M}) \\
\text { Sertifikasi }(\mathrm{M}) \\
\text { Strategi pemasaran }(\mathrm{M}) \\
\text { Pangsa pasar }(\mathrm{M})\end{array}$ \\
\hline
\end{tabular}

Scoring item-item ICD seperti tercantum dalam tabel di atas akan dilakukan dengan cara dikotomus yaitu bernilai 0 jika tidak ada pengungkapan terkait item tersebut, dan bernilai 1 jika ada pengungkapan terkait item tersebut. Kemudian, intellectual capital index akan dihitung dengan menggunakan rumus :

$$
\text { Score }=\frac{\sum d i}{M} x 100 \%
$$




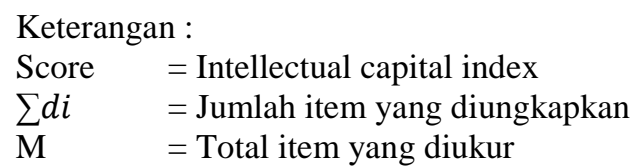

\subsection{VARIABEL INDEPENDEN}

Variabel independen yang digunakan dalam penelitian ini diantaranya board diversity yang terdiri dari perbedaan jenis kelamin, direksi independen, dan size perusahaan.

\subsubsection{Board Diversity}

\section{a. Jenis Kelamin}

Variabel jenis kelamin merupakan salah satu bagian dari board diversity yang penting untuk diteliti dalam hubungannya dengan luas suatu pengungkapan. Beberapa ahli tata kelola menyatakan bahwa keberagaman demografi yang lebih besar diantara anggota dewan perusahaan akan menyebabkan perbaikan dalam kinerja keuangan perusahaan (Daily, Certo, \& Dalton, 1999). Salah satu bagian dari keberagaman demografi adalah jenis kelamin anggota dewan direksi yang direpresentasikan dengan adanya keterwakilan perempuan dalam jajaran direksi. Kehadiran seorang perempuan dalam dewan direksi perusahaan akan membawa perbedaan persepsi sosiologi dan pemahaman dalam pengambilan keputusan yang dilakukan di meja dewan (Swartz, 2006). Perempuan dianggap memiliki rasa terhadap gaya kognitif yang berfokus pada harmoni dan kemampuan untuk memfasilitasi penyebaran informasi (Darmadi, 2012).

Berbagai argumen yang berbeda tentang hadirnya perempuan di dalam dewan direksi berhubungan dengan kompetitif perusahaan (Darmadi, 2012). Beberapa argumen mendukung keterwakilan perempuan di dewan direksi akan membawa keuntungan bagi perusahaan karena perempuan memiliki kepekaan sosial yang baik dan menunjukkan perilaku etis yang lebih baik daripada laki-laki (Hanefah, 2016). Namun, perempuan juga dianggap sulit karena harus menghadapi berbagai tantangan sebelum mendapatkan kursi di dewan (Darmadi, 2012).

Variabel ini gender dalam penelitian ini dilakukan dengan mengukur seberapa banyak keterwakilan perempuan dalam total jumlah dewan direksi di perusahaan. Data jumlah dewan direksi perempuan diambil dari Annual Report, dan pengukurannya dihitung dengan rumus:

\section{b. Direksi Independen}

$$
\text { Direksi Perempuan }=\frac{\text { Jumlah Direksi Perempuan }}{\text { Total Dewan Direksi }}
$$

Variabel dewan direksi independen menunjukkan banyaknya direksi yang bebas dalam suatu dewan perusahaan. Peran direksi independen sangat penting dalam mengawasi kinerja dan perilaku jajaran manajemen atas (Fama dan Jensen, 1983). Peran direksi independen lebih berjalan efektif dibandingkan direksi non independen yang memiliki keterkaitan dengan 
pemegang saham. Sehingga direksi independen cenderung melindungi para pemegang saham terutama yang minoritas dan para investor lainnya (Annuar dan Rasid, 2015). Bahkan proporsi yang lebih besar pada dewan direksi independen akan meningkatkan pengungkapan sukarela karena tidak terikat pada kepentingan salah satu pemilik saham terutama pemilik mayoritas. Maka penting sekali keberadaan dewan direksi independen dalam meningkatkan pengungkapan ICD di suatu perusahaan. Dalam penelitian ini, data jumlah dewan direksi independen diambil dari Annual Report dan variabel independen ini dihitung dengan rasio :

$$
\text { Direksi Independen }=\frac{\text { Jumlah Direksi Independen }}{\text { Total Dewan Direksi }}
$$

\subsubsection{Size Perusahaan}

Size atau ukuran perusahaan merupakan ukuran besar kecilnya suatu perusahaan. Pengukurannya dapat dilakukan dengan berbagai cara , diantaranya dengan total aktiva, log size, nilai pasar saham, dan lain-lain.

Teori stakeholder dapat mendeskripsikan korelasi positif antara ukuran perusahaan dengan pengungkapan intellectual capital. Perusahaan besar akan memperoleh perhatian besar dari para stakeholder, sehingga perusahaan perlu melakukan pengungkapan informasi yang lebih luas, salah satunya adalah informasi mengenai intellectual capital (Sudarmadji \& Sularto, 2007). Perusahaan besar didorong untuk mengungkapkan lebih banyak tentang informasi voluntary, seperti intellectual capital untuk mengurangi biaya keagenan yang dikeluarkan (Jensen \& Meckling, 1976).

Dalam penelitian ini, size perusahaan akan tampak dari nilai total aset yang dimiliki perusahaan. Semakin besar total aset yang dimiliki perusahaan, maka semakin besar ukuranperusahaan tersebut, dan sebaliknya. Perhitungan nilai aset akan diukur dengan menggunakan log natural (ln) dari nilai total aset perusahaan pada akhir tahun.

$$
\text { Size Perusahaan }=\text { Ln Total Aset }
$$

\subsection{JENIS DAN SUMBER DATA}

Jenis data yang digunakan dalam penelitian ini adalah data sekunder. Data sekunder dalam penelitian ini berupa Annual Report (laporan tahunan) masing-masing Bank Umum Syariah secara time series pada tahun 2011 sampai dengan tahun 2015. Sehingga jumlah data yang digunakan selama periode penelitian adalah 50 data dari 10 BUS yang telah diseleksi dengan menggunakan purposive sampling. Data-data dalam penelitian ini bersumber dari website resmi BUS yang diambil dan dikumpulkan dengan cara mengunduh annual report setiap BUS yang menjadi sampel.

\subsection{POPULASI DAN SAMPEL}

Populasi dalam penelitian ini adalah Bank Umum Syariah (BUS) di Indonesia pada tahun 2011 hingga 2015 sebanyak 12 BUS (OJK, 2015). Kemudian dari populasi yang telah ditentukan di atas akan ditarik sampel 
untuk penelitian. Teknik pengambilan sampel yang digunakan adalah purposive sampling dengan kriteria:

a. Bank Umum Syariah di Indonesia;

b. Mempublikasikan annual report pada tahun 2011 sampai dengan tahun 2015;

c. Tersedia data yang lengkap mengenai intellectual capital.

Berdasarkan kriteria yang ditentukan makan didapatkan 10 Bank Umum Syariah (BUS) antara lain Bangk Muamalat Indonesia (BMI), Bank Syariah Mandiri (BSM), Bank Mega Syariah (BMS), Bank Negara Indonesia Syariah (BNIS), Bank Rakyat Indonesia Syariah (BRIS), Bank Central Asia Syariah (BCAS), Bank Panin Syariah (BPS), Bank Syariah Bukopin (BSB), Bank Victoria Syariah (BVS), dan Maybank Syariah Indonesia (MBS).

\subsection{MODEL ANALISIS DATA}

\subsubsection{Content Analysis}

Tahapan analisis yang akan dilakukan terdiri dari:

a. Menganalisa annual report untuk memastikan ada tidaknya pengungkapan item-item ICD seperti yang tercantum dalam Tabel 1.

b. Melakukan scoring terhadap item ICD dengan cara: jika diungkapkan bernilai 1, dan jika tidak diungkapkan bernilai 0 .

c. Setelah mendapat scores dari item-item ICD, kemudian mencari Intellectual capital index dengan rumus yang sudah dijelaskan pada Persamaan 1.

d. Menginterpretasikan hasil index.

e. Hasil dari index tersebut akan digunakan kembali dalam model análisis regresi data panel

\subsubsection{Regresi Data Panel}

Model regresi data panel digunakan untuk menjawab rumusan masalah mengenai pengaruh antara Board Diversity dan Size perusahaan terhadap Intellectual Capital Disclosure. Model regresi data panel akan diolah dengan alat analisis berupa software Eviews versi 9. Model regresi yang digunakan dalam penelitian ini dirumuskan sebagai berikut:

Keterangan:

$$
Y=a+b_{1} X_{1}+b_{2} X_{2}+b_{3} X_{3}+b_{4} X_{4}+\varepsilon
$$

$\mathrm{Y}=$ Intellectual Capital Disclosure

a $=$ Konstanta / koefisien regresi / intercept

$\mathrm{X} 1$ = Jumlah direksi perempuan per total dewan direksi

$\mathrm{X} 2$ = Jumlah direksi independen per total dewan direksi

$\mathrm{X} 3$ = Jumlah direksi asing per total dewan direksi 
$\mathrm{X} 4$ = Size perusahaan (rupiah)

$\mathrm{e} \quad=$ Error (faktor pengganggu)

Data panel memiliki keunggulan dibandingkan dengan data time series dan cross-section. Menurut Hsiao (2003) dan Baltagi (2005) dalam Budhi (2013), keunggulannya adalah sebagai berikut:

a. Estimasi data panel dapat menunjukkan adanya heterogenitas dalam tiap individu;

b. Dengan data panel, data lebih informatif, lebih bervariasi, mengurangi kolinearitas antar variabel, meningkatkan derajat kebebasan (df), dan lebih efisien;

c. Studi data panel lebih memuaskan untuk menentukan perubahan dinamis dibandingkan dengan studi berulang dari cross-section;

d. Data panel membantu studi untuk menganalisis perilaku yang lebih kompleks, misalnya fenomena skala ekonomi dan perubahan teknologi; dan

e. Data panel dapat meminimalkan bias yang dihasilkan agregasi individu atau perusahaan karena unit data lebih banyak.

Dengan berbagai keunggulannya tersebut, untuk penelitian yang menggunakan jenis data panel, menurut Gujarati (2006), Verbeek (2000) dan Sochrul R Ajija, dkk (2011) dalam Yanti dan Safitri (2011) mengatakan bahwa tidak perlu dilakukannya pengujian asumsi klasik.

Pada regresi data panel terdapat tiga pendekatan dalam mengestimasi yaitu common effect, fixed effect dan random effect. Untuk memilih model terbaik dari tiga pendekatan tersebut digunakan uji Chow dan uji Hausman. Uji chow dilakukan dengan melakukan uji statistik F untuk memilih antara pendekatan common effect dan fixed effect. Hasil pengujian dapat dilihat dari nilai probabilitas (Prob.) untuk cross section F, dimana hipotesisnya sebagai berikut:

a. Jika nilai Prob. untuk Cross-Section F > 0,05 maka model yang terpilih adalah Common Effect.

b. Jika nilai Prob. untuk Cross-Section $\mathrm{F}<0,05$ maka model yang terpilih adalah Fixed Effect.

Sementara uji Hausman dilakukan untuk menentukan model terbaik antara pendekatan fixed effect dan random effect. Statistik uji Hausman ini mengikuti distribusi statistik Chi-Squares dengan degree of freedom sebanyak k (variabel independen).Hasil pengujian ini dilihat dari nilai probabilitas (Prob.) untuk Cross-Section random, dimana hipotesisnya adalah sebagai berikut:

a. Jika nilai Prob. untuk cross-section random > 0,05 maka model yang terpilih adalah Random Effect 
b. Jika nilai Prob. untuk cross-section random $<0,05$ maka model yang terpilih adalah Fixed Effect

\section{HASIL DAN PEMBAHASAN}

\subsection{INDEKS INTELLECTUAL CAPITAL DISCLOSURE (ICD) BANK UMUM SYARIAH DI INDONESIA TAHUN 2011-2015}

Hasil content analysis pada tabel 2 menunjukkan indeks ICD untuk sepuluh perbankan syariah yang menjadi sampel penelitian. Bank Syariah Mandiri (BSM) memiliki indeks rata-rata ICD per tahunnya sebesar 0.77. Hal ini menunjukkan dari 36 item pengungkapan Intellectual Capital (IC) terpenuhi sebesar 77\%. Kemudian disusul Bank Muamalat Indonesia (BMI) sebesar 0.74 atau pengungkapan IC di bank tersebut sebesar 74\%. Begitu juga dengan Bank Negara Indonesia Syariah (BNIS), Bank Syariah Bukopin (BSB), Bank Mega Syariah (BMS), Bank Panin Syariah (BPS) dan Bank Rakyat Indoesia Syariah (BRIS) memiliki indeks ICD diatas 0.50 atau 50\% dengan masing-masing sebesar 0.71 (74\%), 0.63 (63\%), 0.57 (57\%), 0.56 (56\%) dan 0.54 (54\%). Sementara Bank Central Asia Syariah (BCAS), Bank Victoria Syariah (BVS) serta Maybank Syariah Indonesia (MBS) memiliki indeks IC di bawah 0.5 (50\%) masing-masing sebesar 0.46 (46\%), 0.44 (44\%) dan 0.34 (34\%).

Tabel 2. Indeks Intellectual Capital Disclosure (ICD) Bank Umum Syariah di Indonesia Tahun 2011-2015

\begin{tabular}{lcccccc}
\hline $\begin{array}{l}\text { Nama } \\
\text { Bank }\end{array}$ & 2011 & 2012 & 2013 & 2014 & 2015 & $\begin{array}{c}\text { Rata-rata } \\
\text { ICD per } \\
\text { tahun }\end{array}$ \\
\cline { 2 - 7 } BSM & 0.78 & 0.75 & 0.75 & 0.81 & 0.75 & 0.77 \\
\hline BMI & 0.69 & 0.72 & 0.81 & 0.72 & 0.78 & 0.74 \\
\hline BNIS & 0.64 & 0.69 & 0.72 & 0.72 & 0.75 & 0.71 \\
\hline BSB & 0.58 & 0.64 & 0.58 & 0.64 & 0.72 & 0.63 \\
\hline BMS & 0.53 & 0.50 & 0.53 & 0.67 & 0.61 & 0.57 \\
\hline BPS & 0.47 & 0.50 & 0.58 & 0.61 & 0.64 & 0.56 \\
\hline BRIS & 0.50 & 0.56 & 0.58 & 0.56 & 0.53 & 0.54 \\
\hline BCAS & 0.44 & 0.50 & 0.44 & 0.44 & 0.47 & 0.46 \\
\hline BVS & 0.42 & 0.44 & 0.47 & 0.44 & 0.44 & 0.44 \\
\hline MBS & 0.31 & 0.33 & 0.33 & 0.36 & 0.39 & 0.34 \\
\hline
\end{tabular}

Sumber: Data sekunder yang diolah (2017)

Pada Tabel 3 menunjukkan indeks ICD dari komponen secara keseluruhan dan jika dilihat dari komponen Human Capital, Structure Capital dan Relational Capital. Jika dilihat dari indeks ICD (Tabel 3) secara keseluruhan dari sepuluh perbankan syariah terlihat terjadi peningkatan pengungkapan item intellectual capital dari tahun 2011 hingga 2015. Indeks ICD tahun 2011 sebesar 0.54 atau sebesar 54\% dari 36 total item pengungkapan IC (19 item) diumumkan pada laporan tahunan. Nilai tersebut 
terus naik hingga tahun 2015 dengan rata-rata sebanyak 22 item IC diungkapkan pada laporan tahunan.

Jika dilihat per komponen penyusun ICD terlihat bahwa pengungkapan Human Capital masih tergolong relatif rendah. Namun terjadi peningkatan cukup signifikan dari indeks ICD sebesar 0,56 tahun 2011 menjadi 0,68 di tahun 2015. Sementara itu indeks pengungkapan structur capital pada perbankan syariah juga masih relative rendah sebesar 0,58 di tahun 2011 dan mengalami peningkatan menjadi 0,62 pada tahun 2015. Lain halnya pada komponen relational capital yang memiliki indeks ICD di bawah 0,5 yaitu sebesar 0,47 juga mengalami peningkatan menjadi 0,55 di tahun 2015.

Peningkatan indeks ICD pada perbankan syariah menjadi sinyal baik dimana peningatan indeks tersebut akan berdampak pada meningkatnya pendapatan perusahaan. Sesuai dengan yang diungkapkan oleh Suhardjanto dan Wardhani (2007) bahwa suatu perusahaan akan mudah menjalin hubungan yang baik dengan pelanggan jika suatu perusahaan memiliki human capital cerdas dan structur capital yang bagus dan relational capital yang baik akan berdampak pada meningkatnya pendapatan perusahaan.

Tabel 3. Agregat Indeks ICD per komponen sepuluh Bank Umum Syariah di Indonesia Tahun 2011-2015

\begin{tabular}{lccccc}
\hline $\begin{array}{l}\text { Komponen } \\
\text { ICD }\end{array}$ & 2011 & 2012 & 2013 & 2014 & 2015 \\
\hline $\begin{array}{l}\text { Human } \\
\text { Capital }\end{array}$ & 0.56 & 0.60 & 0.61 & 0.64 & 0.68 \\
\hline $\begin{array}{l}\text { Structure } \\
\text { Capital }\end{array}$ & 0.58 & 0.60 & 0.59 & 0.61 & 0.62 \\
\hline $\begin{array}{l}\text { Relational } \\
\text { Capital }\end{array}$ & 0.47 & 0.50 & 0.55 & 0.55 & 0.55 \\
\hline Total Indeks & 0.54 & 0.56 & 0.58 & 0.60 & 0.61 \\
\hline
\end{tabular}

\subsection{BOARD DIVERSITY}

\subsubsection{Jenis Kelamin Direksi}

Proporsi direksi perempuan pada Tabel 4 dihitung berdasarkan jumlah direksi perempuan pada suatu BUS dibandingkan dengan total dewan direksi pada BUS tersebut. Pada tabel tersebut terlihat bahwa rata-rata jumlah perempuan pada kursi direksi BUS Indonesia hanya sebesar $21 \%$.

Tabel 4. Proporsi Direksi Perempuan Bank Umum Syariah

\begin{tabular}{llcccccc}
\hline & & \multicolumn{7}{c}{ Proporsi Direksi Perempuan } & $\begin{array}{c}\text { Rata- } \\
\text { rata } \\
\text { No }\end{array}$ & $\begin{array}{c}\text { Nama } \\
\text { Bank }\end{array}$ & 2011 & 2012 & 2013 & 2014 & 2015 & $\begin{array}{c}\text { per } \\
\text { Tahun }\end{array}$ \\
\hline 1 & BSM & 0 & 0 & 0 & 0 & 0 & $0 \%$ \\
\hline 2 & BMI & 0.2 & 0.2 & 0.2 & 0.2 & 0.2 & $20 \%$ \\
\hline 3 & BNIS & 0 & 0 & 0 & 0 & 0 & $0 \%$ \\
\hline 4 & BSB & 0 & 0 & 0 & 0 & 0 & $0 \%$ \\
\hline
\end{tabular}




\begin{tabular}{llcccccc}
\hline 5 & BMS & 0.4 & 0.4 & 0.25 & 0.25 & 0.33 & $33 \%$ \\
\hline 6 & BPS & 0.25 & 0.25 & 0.25 & 0.25 & 0.25 & $25 \%$ \\
\hline 7 & BRIS & 0 & 0 & 0 & 0 & 0 & $0 \%$ \\
\hline 8 & BCAS & 0.67 & 0.67 & 0.67 & 0.67 & 0.67 & $67 \%$ \\
\hline 9 & BVS & 0.33 & 0.33 & 0.5 & 0.5 & 0.25 & $38 \%$ \\
\hline 10 & MBA & 0.33 & 0.33 & 0.33 & 0.33 & 0.25 & $32 \%$ \\
\hline & Total & 2.18 & 2.18 & 2.2 & 2.2 & 1.95 & \\
\hline & $\begin{array}{l}\text { Rata- } \\
\text { rata } \\
\text { per }\end{array}$ & 0.218 & 0.218 & 0.22 & 0.22 & 0.195 & $21 \%$ \\
& & & & & & \\
\hline & & & & & & \\
\hline
\end{tabular}

Sumber: Data Sekunder yang diolah (2017)

Jika dilihat dari jumlah Bank yang menempatkan direksi perempuan pada jajaran dewan direksi sebanya 6 Bank dari total 10 Bank yang menjadi sampel penelitian. Berarti secara umum dapat digambarkan bahwa $60 \%$ BUS di Indonesia telah memperhatikan hadirnya perempuan dalam posisi manajemen puncak sebagai bentuk kesetaraan gender.

Proporsi perempuan terbanyak terdapat pada Bank Central Asia Syariah (BCAS) sebesar $67.7 \%$ tiap tahunnya. Hal ini menjunjukkan bahwa bank tersebut tiap tahun menempatkan 2 orang direksi perempuan dari total tiga kursi dewan direksi yang tersedia. Sementara Bank Syariah Mandiri (BSM), Bank Negara Indonesia Syariah (BNIS), Bank Syariah Bukopin (BSB) dan Bank Rakyat Indonesia Syariah (BRIS) yang termasuk bank terbesar tidak menempatkan satu pun perempuan dalam kursi dewan direksi tiap tahunnya.

\subsubsection{Direksi Independen}

Independensi seorang direktur dapat dipenuhi apabila yang bersangkutan tidak memiliki hubungan keuangan, kepengurusan, kepemilikan sama dan/atau hubungan keluarga dengan pemegang saham pengendali BUS. Dalam hal ini direksi independen diproksikan dengan perbandingan jumlah direksi yang bersifat independen terhadap total dewan direksi secara keseluruhan.

Tabel 5. Proporsi Direksi Independen Bank Umum Syariah

\begin{tabular}{llcccccc}
\hline \multirow{2}{*}{ No } & $\begin{array}{c}\text { Nama } \\
\text { Bank }\end{array}$ & 2011 & 2012 & 2013 & 2014 & 2015 & $\begin{array}{c}\text { Rata- } \\
\text { rata per } \\
\text { Tahun }\end{array}$ \\
\hline 1 & BSM & 1 & 1 & 1 & 1 & 1 & $100 \%$ \\
\hline 2 & BMI & 0.8 & 0.8 & 0.8 & 0.8 & 1 & $84 \%$ \\
\hline 3 & BNIS & 1 & 1 & 1 & 1 & 1 & $100 \%$ \\
\hline 4 & BSB & 1 & 1 & 1 & 1 & 1 & $100 \%$ \\
\hline 5 & BMS & 1 & 1 & 1 & 1 & 1 & $100 \%$ \\
\hline 6 & BPS & 1 & 1 & 1 & 1 & 1 & $100 \%$ \\
\hline 7 & BRIS & 1 & 1 & 1 & 1 & 0.6 & $92 \%$ \\
\hline
\end{tabular}




\begin{tabular}{llcccccc}
\hline 8 & BCAS & 1 & 1 & 1 & 1 & 1 & $100 \%$ \\
\hline 9 & BVS & 1 & 1 & 1 & 1 & 1 & $100 \%$ \\
\hline 10 & MBA & 1 & 1 & 1 & 1 & 1 & $100 \%$ \\
\hline & Total & 9.8 & 9.8 & 9.8 & 9.8 & 9.6 & \\
\hline & $\begin{array}{l}\text { Rata- } \\
\text { rata }\end{array}$ & 0.98 & 0.98 & 0.98 & 0.98 & 0.96 & $98 \%$ \\
& per & & & & & & \\
& Bank & & & & & & \\
\hline
\end{tabular}

Sumber: Data Sekunder yang diolah (2017)

Berdasarkan data yang diperoleh (Tabel 5), hampir seluruh dewan direksi setiap bank bersifat independen. Hanya BMI selama 4 tahun awal penelitian mempunyai 1 orang yang merangkap jabatan sebagai komisaris Al-Ijarah, dan BRIS pada tahun 2015 mempunyai 2 orang direksi sebagai pemegang saham pengendali BRIS. Namun hal tersebut masih sesuai dengan Surat Edaran BI No. 12/13/DPbs poin C.1 tentang Pelaksanaan GCG bagi BUS dan UUS yang menyatakan bahwa Presiden Direktur atau Direktur Utama wajib berasal dari pihak yang independen terhadap pemegang saham pengendali, karena direksi BMI dan BRIS yang tidak independen tersebut bukan menjabat sebagai Direktur Utama.

\subsubsection{Size Perusahaan}

Untuk size perusahaan diproksikan dengan menggunakan total asset.Berdasarkan tabel 6, ukuran BUS terbesar dimiliki oleh BSM dengan aset sebesar Rp 60.835,60 miliar, mengungguli BUS tertua yaitu BMI dengan total aset sebanyak Rp 50.322,80 miliar. Ukuran BUS ini tidak terlepas dari pengalaman karirnya di dunia perbankan syariah sebagai BUS. Seperti BSM dan BMI sebagai pengawal berdirinya bank syariah, telah berhasil mengukuhkan lembaganya diurutan atas sebagai BUS terbesar. Di sudut berbeda, BUS dengan jumlah total aset terkecil dimiliki oleh BVS dengan perolehan rata-rata aset sebesar Rp 1.144,60 miliar. Bank ini mengalami penurunan pada tahun 2015 setelah mengalami kenaikan terus menerus dari tahun 2011. Total aset terkecil pun terdapat pada BVS ditahun 2011 dengan nilai Rp 642 miliar. Hal ini dapat disebabkan karena ekspansi dan jaringan distribusi BVS yang masih sangat terbatas.

Tabel 6. Size Bank Umum Syariah Periode 2011-2015

\begin{tabular}{lllcccrc}
\hline \multirow{2}{*}{ No } & Nama & \multicolumn{5}{c}{ Size Perusahaan } & \multirow{2}{*}{$\begin{array}{l}\text { Rata-rata } \\
\text { per tahun }\end{array}$} \\
\cline { 3 - 8 } & Bank & 2011 & 2012 & 2013 & 2014 & 2015 & \\
\hline 1 & BSM & 48.672 & 54.229 & 63.965 & 66.942 & 70.370 & $60.835,60$ \\
\hline 2 & BMI & 32.480 & 44.854 & 54.694 & 62.413 & 57.173 & $50.322,80$ \\
\hline 3 & BNIS & 8.467 & 10.645 & 14.709 & 19.492 & 23.018 & $15.266,20$ \\
\hline 4 & BSB & 2.730 & 3.616 & 4.343 & 5.161 & 5.827 & $4.335,40$ \\
\hline 5 & BMS & 5.565 & 8.164 & 9.122 & 7.042 & 5.560 & $7.090,60$ \\
\hline 6 & BPS & 1.017 & 2.137 & 4.053 & 6.207 & 7.134 & $4.190,60$ \\
\hline
\end{tabular}




\begin{tabular}{llrrrrrr}
\hline 7 & BRIS & 11.201 & 14.089 & 17.401 & 20.343 & 24.230 & $17.452,80$ \\
\hline 8 & BCAS & 1.217 & 1.602 & 2.041 & 2.994 & 4.350 & $2.440,80$ \\
\hline 9 & BVS & 642 & 939 & 1.323 & 1.440 & 1.379 & $1.144,60$ \\
\hline 10 & MBS & 1.693 & 2.063 & 2.300 & 2.450 & 1.743 & $2.049,80$ \\
\hline & Total & 113.684 & 142.338 & 173.951 & 194.484 & 200.784 & \\
\hline & $\begin{array}{l}\text { Rata- } \\
\text { rata } \\
\text { per } \\
\text { Bank }\end{array}$ & $11.368,40$ & $14.233,80$ & $17.395,10$ & $19.448,40$ & $20.078,40$ & 16.505 \\
& & & & & & \\
\hline
\end{tabular}

Sumber: Data Sekunder yang diolah (2017)

\subsection{ANALISIS REGRESI DATA PANEL}

\subsubsection{Hasil Uji Chow dan Hausman}

Untuk pemilihan model terbaik melalui Uji Chow dan Uji Hausman dapat dilihat pada Tabel 7. Hasil Uji Chow terlihat nilai probabilitas cross-section $F$ sebesar 0,000 yang berarti lebih kecil dari tingkat signifikansi 5\% $(0,05)$. Sehingga dapat disimpulkan bahwa model fixed effect lebih baik dibandingkan model PLS. Sementara pada uji Hausmann terlihat bahwa nilai probabilitas cross-section sebesar 0.9194 lebih dari tingkat signifikansi 5\% $(0,05)$. Hali ini menunjukkan bahwa model random effect merupakan model terbaik dalam regresi data panel dibandingkan model fixed effect.

Tabel 7. Hasil Uji Chow dan Uji Hausmann

\begin{tabular}{lcccccc}
\hline & \multicolumn{3}{c}{ Uji Chow } & \multicolumn{3}{c}{ Uji Hausmann } \\
\cline { 2 - 7 } & F Stat. & d.f. & Prob. & $\begin{array}{c}\text { Chi-sq. } \\
\text { Stat. }\end{array}$ & $\begin{array}{c}\text { Chi-Sq. } \\
\text { d.f. }\end{array}$ & Prob. \\
\hline $\begin{array}{l}\text { Cross- } \\
\text { section }\end{array}$ & 16.786808 & $(9,37)$ & 0.0000 & 0.497536 & 3 & 0.9194 \\
\hline
\end{tabular}

Sumber: Hasil Output Eviews 9

\subsubsection{Model Regresi Data Panel}

Berikut merupakan hasil dari estimasi random effect model yang telah melalui tahap pengujian sehingga terpilih sebagai model terbaik.

Tabel 8. Hasil Estimasi Random Effect Model

\begin{tabular}{lcr}
\hline \multicolumn{1}{c}{ Variabel } & Coefficient & Prob. \\
\hline Gender & $-0.169603^{*}$ & 0.0739 \\
\hline Independen & $0.135125^{* * *}$ & 0.1480 \\
\hline Size & $0.068906^{* * *}$ & 0.0000 \\
\hline $\mathrm{C}$ & $-1.556941^{* * *}$ & 0.0003 \\
\hline $\mathrm{R} 2$ & 0.490125 & \\
\hline $\begin{array}{l}\text { Prob(F- } \\
\text { statistic) }\end{array}$ & 0.000001 & \\
\hline$* * * * * *$ signigikan pada $1 \%, 5 \%, 10 \%$ &
\end{tabular}


Persamaan regresi yang dapat dibuat berdasarkan hasil estimasi tersebut adalah sebagai berikut:

ICD = -1,556941 - 0,169603 GENDER + 0,135125 IND + 0,068906 SIZE + $\mathrm{e}$

Nilai $\mathrm{R}^{2}$ yang mendekati angka 1 mempunyai makna kecocokan regresi yang semakin besar, sebaliknya jika mendekati angka 0 maka tingkat error dalam persamaan regresi yang akan semakin besar. Melalui $\mathrm{R}^{2}$ ini dapat terlihat seberapa besar kemampuan variabel independen menjelaskan variabel dependennya. Berdasarkan hasil pengujian yang ada dalam tabel 8 , nilai koefisien determinasi (R-squared) yang diperoleh sebesar 0,490125. Artinya, seluruh variabel independen yang digunakan dalam persamaan regresi ini memiliki 49\% kecocokan dalam menjelaskan luas ICD BUS. Sedangkan 51\% sisanya dipengaruhi oleh variabel lain yang tidak diteliti dalam penelitian ini.

Pengujian simultan (F hitung) dilakukan dengan menggunakan taraf nyata level $0.05(\propto=5 \%)$. Pada tabel 8 terlihat nilai probabilitas $\mathrm{F}$ hitung sebesar 0,000001 kurang dari taraf nyata 0,05 menunjukkan bahwa direksi perempuan (gender), independensi dewan direksi (independen), Ukuran perusahaan (size) berpengaruh secara simultan terhadap Intelectual Capital Disclosure (ICD) pada taraf nyata $0,05(\alpha=5 \%)$.

H1: Board diversity berupa Jenis kelamin dewan direksi berpengaruh positif dan signifikan terhadap intellectual capital disclosre

Berdasarkan hasil uji parsial (t-hitung) struktur direksi perempuan (GENDER) berpengaruh negatif terhadap ICD dengan nilai probabilitas 0,0739 kurang dari 0,1 (alpha 10\%). Hasil ini menunjukkan H1 diterima artinya bahwa direksi perempuan (GENDER) berpengaruh signifikan terhadap ICD. Pengaruh negatif ini Hal ini berbeda dengan penelitian yang dilakukan Swartz S. Firer (2006) yang menyatakan bahwa gender tidak berpengaruh signifikan terhadap Intelectual Capital. Hal tersebut dikarenakan masih rendahnya tingkat partisipasi perempuan dalam jajaran direksi (Zald, 1969). Selain itu secara tradisional perempuan terkadang banyak menghadapi berbagai tantangan sebelum mendapatkan kursi di dewan dan selain itu juga masih dianggap sulit dalam menjalankan tugas strategis pada posisi dewan direksi.

$\mathrm{H} 2$ : Board diversity berupa dewan direksi independen berpengaruh positif dan signifikan terhadap intellectual capital disclosure

Probabilitas dewan direksi independen (INDEPENDEN) pada hasil uji parsial sebesar 0,1480 lebih dari nilai signifikansi 0,05 (alpha $=5 \%)$ dan 0,10 $($ alpha $=10 \%)$. Hal ini menunjukkan hipotesis $\mathrm{H} 2$ ditolak artinya bahwa dewan direksi independen tidak memiliki pengaruh signifikan terhadap ICD. Hal ini tidak sesuai dengan penelitian yang dilakukan M. Al-Musalli dan K. Ismail (2012) yang menyatakan bahwa direktur independen berpengaruh positif terhadap ICD.

Tidak berpengaruhnya dewan direksi independen terhadap ICD, salah satunya diakibatkan tidak berjalan efektifnya peran direksi independen pada 
perusahaan perbankan syariah. Faktor rendahnya kecakapan dari pribadi dewan direksi independen dalam menjalankan tugas monitoring mengakibatkan tidak terungkapnya secara luas item-item ICD. Selain itu dimungkinkan dari sikap kehati-hatian dari dewan direksi independen dalam mengungkapkan ICD untuk memproteksi informasi-informasi strategis dari para pesaing perusahaan.

H3: Size perusahaan berpengaruh positif dan signifikan terhadap intellectual capital disclosure

Pada tabel 8 menunjukkan hasil uji parsial ukuran perusahaan terhadap pengungkapan ICD pada nilai probabilitas 0,0000 kurang dari taraf nyata 0,05 (alpha $=5 \%$ ). Hasil ini menunjukkan bahwa hipotesis $\mathrm{H} 3$ diterima yang artinya bahwa ukuran perusahaan berpengaruh signifikan terhadap ICD pada alpha 5\%. Hasil ini sejalan dengan hasil penelitian Theresya Stephani dan Etna N. A. Yuyetta (2011) yang menyatakan bahwa ukuran perusahaan memiliki berpengaruh positif terhadap ICD.

Menurut Jensen dan Meckling (1976), perusahan besar memiliki proporsi modal eksternal yang cenderung besar. Dengan bertambahnya proporsi modal eksternal akan berdampak pada meningkatnya biaya keagenan. Oleh karena itu, diperlukan pelaporan baik informasi finansial maupun informasi non-finansial sebagai wujud pertangungjawaban kepada para pemilik modal. Sehingga perusahaan besar merasa perlu untuk melakukan pengungkapan informasi tersebut untuk meminimalisir biaya keagenan.

\section{SIMPULAN}

Pengungkapan intellectual capital dengan menggunakan analisis konten pada perbankan syariah di Indonesia pada periode 2011 hingga 2015 mengalami peningkatan. Hal tersebut terlihat dari besaran indeks ICD secara agregat pada tahun 2011 sebesar 0,54 menjadi 0,61 di tahun 2015. Kenaikan tersebut di dorong oleh kenaikan komponen-komponen dari ICD seperti human capital, structure capital dan relational capital. Semakin banyak pengungkapan IC yang dilakukan perbankan syariah akan berdampak pada peningkatan pendapatan dan kepercayaan dari para stakeholder.

Sementara melalui analisis data panel untuk menguji hipotesis secara simultan terlihat jelas bahwa board diversity dan ukuran perusahaan (size) memiliki pengaruh signifikan pada pengungkapan ICD pada perusahaan perbankan di Indonesia. Namun jika dilihat dari pengaruhnya secara parsial, peran board diversity tidak memiliki pengaruh positif terhadap ICD secara luas. Bahkan board diversity dari aspek independensi dewan direksi tidak banyak membantu dalam meningkatkan pengungkapan ICD pada perbankan syariah di Indonesia. Namun faktor lainnya seperti ukuran perusahaan (size) memiliki pengaruh positif dalam memperbanyak item-item pengungkapan ICD. 


\section{DAFTAR PUSTAKA}

Al-Musalli, M. A. K., \& Ismail, K. N. I. K. (2012). Intellectual capital performance and board characteristics of GCC banks. Procedia Economics and Finance, 2, 219-226.

Annuar, H. A., \& Abdul Rashid, H. M. (2015). An investigation of the control role and effectiveness of independent non-executive directors in Malaysian public listed companies. Managerial Auditing Journal, 30(6/7), 582-609.

Astuti, N. M. A., \& Wirama, D. G. (2016). Pengaruh Ukuran Perusahaan, Tipe Industri Dan Intensitas Research And Development Pada Pengungkapan Modal Intelektual. E-Jurnal Akuntansi Universitas Udayana, 15, 522-548

Budhi, S., \& Kembar, M. (2013). Analisis Faktor-faktor Yang Berpengaruh Terhadap Pengentasan Kemiskinan Di Bali: Analisis FEM Data Panel. Jurnal Ekonomi Kuantitatif Terapan, 6(1), 1-6

Brüggen, A., Vergauwen, P., \& Dao, M. (2009). Determinants of intellectual capital disclosure: evidence from Australia. Management decision, 47(2), 233-245.

Ming Chen, H., \& Jun Lin, K. (2004). The role of human capital cost in accounting. Journal of intellectual capital, 5(1), 116-130.

Daily, C. M., Certo, S. T., \& Dalton, D. R. (1999). A decade of corporate women: Some progress in the boardroom, none in the executive suite. Strategic Management Journal, 93-99.

Darmadi, S. (2012). Board Diversity and Firm Performance: The Indonesian Evidence. Munich Personal RePEc Archive, (38721)

Edvinsson, L., \& Sullivan, P. (1996). Developing a model for managing intellectual capital. European management journal, 14(4), 356-364.

Fama, E. F., \& Jensen, M. C. (1983). Separation of ownership and control. The journal of law and Economics, 26(2), 301-325.

Guthrie, J., Petty, R., Yongvanich, K., \& Ricceri, F. (2004). Using content analysis as a research method to inquire into intellectual capital reporting. Journal of intellectual capital, 5(2), 282-293.

Hanefah, A. H. I. M. M. (2016). Board Diversity and Corporate Social Responsibility in Jordan. Journal of Financial Reporting and Accounting, 14(2)

Harrison, S., \& Sullivan Sr, P. H. (2000). Profiting from intellectual capital: learning from leading companies. Journal of intellectual capital, 1(1), 33-46. 
Jensen, M. C., \& Meckling, W. H. (1976). Theory of the firm: Managerial behavior, agency costs and ownership structure. Journal of financial economics, 3(4), 305-360.

Mouritsen, J., Thorbjørnsen, S., Bukh, P. N., \& Johansen, M. R. (2004). Intellectual capital and new public management: Reintroducing enterprise. The Learning Organization, 11(4/5), 380-392.

Artinah, B., \& Muslih, A. (2016). Pengaruh Intellectual Capital terhadap Capital Gain (Studi Empiris terhadap Perusahaan Perbankan yang Terdaftar di Bursa Efek Indonesia). JURNAL ILMIAH BISNIS dan KEUANGAN, 1(1).

OJK. (2015). Otoritas Jasa Keuangan

Oktavianti, H. (2014). Faktor-Faktor yang Mempengaruhi Pengungkapan Intellectual Capital. Jurnal Ilmu dan Riset Akuntansi, 3(5).

Rupidara, N. (2008, February). Modal Intelektual dan Strategi Pengembangan Organisasi dan Sumber Daya Manusia. In Dipresentasikan pada Forum Diskusi PSKTI Universitas Kristen Satya Wacana tanggal 21 Februari 2008.

Sawarjuwono, T., \& Kadir, A. P. (2004). Intellectual Capital: Perlakuan, Pengukuran dan Pelaporan (Sebuah Library Research). Jurnal Akuntansi dan Keuangan, 5(1), pp-35.-37

Stephani, T., \& Yuyetta, E. N. A. (2011). Analisis Faktor-faktor yang Mempengaruhi Intellectual Capital Disclosure (ICD). Jurnal Akuntansi dan Auditing, 7(2), 111-121.

Sudarmadji, A. M., \& Sularto, L. (2007). Pengaruh ukuran perusahaan, profitabilitas, leverage, dan tipe kepemilikan perusahaan terhadap luas. Proceeding PESAT Gunadarma, 2, 21-22

Suhardjanto, D., \& Wardhani, M. (2010). Praktik intellectual capital disclosure perusahaan yang terdaftar di bursa efek Indonesia. Jurnal Akuntansi dan Auditing Indonesia, 14(1), 71-85

Swartz, N. P., \& Firer, S. (2005). Board structure and intellectual capital performance in South Africa. Meditari Accountancy Research, 13(2), 145-166.

Ulum, I. (2009). Intellectual Capital Performance Sektor Perbankan di Indonesia. Jurnal Akuntansi dan Keuangan, 10(2), pp 77-84

Ulum, I., Ghozali, I., \& Chariri, A. (2008). Intellectual Capital Dan Kinerja Keuangan Perusahaan; Suatu Analisis Dengan Pendekatan Partial Least Squares. Simposium Nasional Akuntansi XI, 19(19), 23-24

Ulum, I. (2011). Analisis praktik pengungkapan informasi intellectual capital dalam laporan tahunan perusahaan telekomunikasi di Indonesia. Jurnal Reviu Akuntansi dan Keuangan, 1(1), 49-56 
Ulum, I. (2016). Intellectual capital disclosure: Suatu analisis dengan four way numerical coding system. Jurnal Akuntansi dan Auditing Indonesia, 19(1), 39-50.

Umar, H. (2000). Research methods in finance and banking. Jakarta: PT Gramedia Pustaka Utama.

Yanti, O. D., \& Safitri, E. (2011). Pengaruh Faktor-Faktor Fundamental Terhadap Harga Saham LQ45 Di Bursa Efek Indonesia ( BEI ). MDP. Dipetik Oktober 2016: http://eprints.mdp.ac.id/930/1/jurnal-okta.pdf

Zald, M. N. (1969). The power and functions of boards of directors: A theoretical synthesis. American journal of Sociology, 75(1), 97-111. 